\title{
Pengembangan Model Pembelajaran Berbasis Proyek Dalam Menulis Teks Eksplanasi di Kelas XI SMA
}

\author{
Wagirun $^{\mathrm{a}, \mathbf{1}}$ dan Bambang Irawan ${ }^{\mathrm{a}, 2}$ \\ aUniversitas Muslim Nusantara Al Wasliyah Medan \\ 11wagirunsasmita@yahoo.co.id; ${ }^{1}$ bambangirawan@gmail.com \\ Article info ABSTRACT
}

Article history:

Received: 25-08-2019

Revised : 28-09-2019

Accepted: 27-10-2019

This study aims to describe the effectiveness of the use of project-based learning models. The stages of this research development include: (1) literature and field studies; (2) analysis of learning models, initial product design; and (3) evaluation. The instruments used were nontest and test. Non-test instruments use a questionnaire and test instruments use pre-test and post-test. The pre-test and post-test results show that the project-based learning model can effectively improve the ability to write explanatory texts in class XI MIA-1 students at SMA Negeri 1 Labuhan Deli in 2018/2019.

Keywords: ability explanatory texts project-based learning models questionnaire

Penelitian ini bertujuan untuk mendeskripsikan efektivitas penggunaan model pembelajaran berbasis proyek. Tahapan penelitian pengembangan ini, meliputi: (1) studi literatur dan lapangan; (2) analisis model pembelajaran, desain produk awal; dan (3) evaluasi. Instrumen yang digunakan adalah nontes dan tes. Instrumen nontes menggunakan angket dan instrumen tes menggunakan pre-tes dan pos-tes. Hasil pre-tes dan pos-tes menunjukkan bahwa model pembelajaran berbasis proyek efektif dapat meningkatkan kemampuan menulis teks eksplanasi pada siswa kelas XI MIA-1 SMA Negeri 1 Labuhan Deli Tahun Pelajaran 2018/2019.

Copyright $@ 2019$ Institut Agama Islam Negeri Syekh Nurjati Cirebon. All rights reserved.

\section{PENDAHULUAN}

Pembelajaran bahasa Indonesia saat ini bersentuhan dengan teks, tetapi pembelajaran berbasis teks baru dikenalkan dalam kurikulum 2013. Implementasi pembelajaran berbasis teks diharapkan akan mampu memberikan warna baru dalam pembelajaran bahasa Indonesia di era global sekarang ini. Selain itu, dalam pembelajaran teks terutama teks eksplanasi selalu berkaitan dengan keterampilan menulis yang ada dalam standar isi kurikulum 2013. Dengan berbasis, teks siswa pembelajaran bahasa Indonesia mampu menyajikan suatu materi yang dapat membangun struktur berpikir peserta didik. Hal itu disebabkan satuan bahasa yang memiliki struktur berpikir lengkap sesuai konteks situasinya adalah teks. Teks eksplanasi dibuat untuk menjelaskan proses terjadinya sesuatu secara rinci dan termasuk ke dalam klasifikasi tanggapan (Azkia \& Isnandab, 2018). Berbeda jenis teks, berbeda struktur berpikirnya. Dengan demikian semakin banyak teks yang 
dikuasai peserta didik, akan semakin banyak banyak pula struktur berpikir yang dikuasainya. Seorang pesrta didik akan mampu memilih struktur berpikir dalam berbagai jenis teks untuk satu topik tergantung tujuan sosial yang hendak dicapai melalui penggunaan bahasa tersebut baik lisan maupun tulis.

Menulis adalah salah satu keterampilan berbahasa dan merupakan suatu kegiatan yang mempunyai hubungan dengan proses berpikir serta keterampilan berekspresi dalam bentuk tulisan (Khairullah, Syambasril, \& Wartiningsih, 2019). Pentingnya kegiatan menulis bagi peserta didik ialah melatih pemahaman dalam ilmu berbahasa dan merupakan kegiatan yang produktif yaitu sebagai sebuah proses berkesinambungan dan menghasilkan produk. Selain itu, menulis membuat seseorang mampu berpikir kreatif, inisiatif, dan meningkatkan kecerdasan dalam akademis (Wardiani \& Mulyaningsih, 2015).

Berdasarkan hasil observasi awal direkomendasikan sebuah model pembelajaran yang dianggap tepat, yaitu model pembelajaran berbasis proyek (Project Based Learning). Model pembelajaran ini merupakan model pembelajaran yang proses pembelajarannya diarahkan untuk mengaktifkan pembelajar guna membangun pengetahuan dan keterampilan serta nilai-nilai juga sikap melalui pengalamannya secara langsung.

Model pembelajaran berbasis proyek menawarkan kegiatan pembelajaran yang menyenangkan, bermakna, dan kooperatif bagi peserta didik. Model pembelajaran ini memungkinkan peserta didik untuk lebih berekspresi dalam kegiatan pembelajaran dibandingkan dengan model pembelajaran yang selama ini dilaksanakan karena model pembelajaran ini pikiran peserta didik akan lebih segar dan dapat mengambil bagian-bagian dari alam dan pengalamannya di lapangan tentang fenomena-fenomena baik alam maupun sosial untuk dijadikan sumber atau ide dalam penulisan teks eksplanasi.

Penelitian Saragih (2013) menunjukkan bahwa ada pengaruh yang signifikan penerapan model pembelajaran berbasis proyek terhadap kemampuan menulis teks observasi. Ini terbukti dari pengujian hipotesis, yaitu $\mathrm{t}$ hitung $>$ tabel (7,06 > 2,03). Demikian juga dengan penelitian Susilo (2017) yang menunjukkan adanya kenaikan keterampilan siswa dalam menulis teks eksplanasi. Penelitian Nugraha \& Sari (2019) menunjukkan bahwa metode pembelajaran berbasis masalah dinilai efektif dalam pembelajaran menyusun teks eksplanasi. 


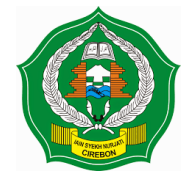

Model pembelajaran dapat diklarifikasi berdasarkan tujuan pembelajaran, sintaknya (langkah-langkahnya), dan sifat lingkungan belajarnya. Menurut Karli dan Yulirtianingsih (dalam Ngalimun, 2012), ada banyak model pembelajaran yang dapat digunakan dalam implementasi pembelajaran di antaranya: pembelajaran konstektual (CTL), pembelajaran berdasarkan masalah, pembelajaran konstruktivisme, dengan pendekatan kolaboratif, pengajaran langsung, pembelajaran terpadu, pembelajaran interaktif, pembelajaran berbasis proyek, dan pembelajaran koopratif.

Pembelajaran berbasis proyek, merupakan salah satu model pembelajaran yang dikembangkan dalam kegiatan belajar mengajar. Ada beberapa pengertian mengenai pembelajaran berbasis proyek. Wena (2011) menyatakan bahwa pembelajaran berbasis proyek sebagai model pembelajaran yang melibatkan peserta didik dalam transfer pengetahuan. Boss dan Kraus dalam Abidin (2007) mendefinisikan model pembelajaran berbasis proyek merupakan sebuah model pembelajaran yang menekankan aktivitas siswa dalam memecahkan berbagai permasalahan yang bersifat open-ended dan mengaplikasi pengetahuan mereka dalam mengerjakan sebuah proyek untuk menghasilkan sebuah produk otentik tertentu. Model pembelajaran ini lebih jauh dipandang sebagai sebuah model pembelajaran yang sangat baik digunakan untuk mengembangkan rasa percaya diri, meningkatkan kemampuan memecahkan masalah, dan membiasakan siswa menggunakan kemampuan berpikir tinggi.

\section{METODE}

Penelitian pengembangan (Research \& Develoment) ini melibatkan siswa kelas XI SMA Negeri 1 Labuhan Deli yang terdiri atas 6 kelas dengan jumlah siswa 208 orang dan dua guru bahasa Indonesia. Sampel penelitian dipilih secara acak sederhana, yaitu kelas XI MIA-1 (Sugiyono, 2015). Data dikumpulkan melalui tes menulis teks eksplanasi. Selain itu, data juga dikumpulkan melalui nontes berupa angket, yaitu: angket faktor menulis siswa, angket uji validasi, dan angket umpan balik. Penelitian ini menggunakan skala Likert yang sudah dimodifikasi untuk mengetahui minat belajar siswa dengan rumus: $\mathrm{T}$ x $\mathrm{Pn}$. ( $\mathrm{T}=$ Total Jumlah responden yang memilih, Pn= Pilihan Angka Skor Likert). Untuk 
mendapatkan hasil interprestasi, harus diketahui terlebih dahulu skor total ideal (X) dan skor rendah (Y). Berikut rumus penilaian untuk mendapatkan hasil interprestasi.

Skala Ideal $(\mathrm{X}) \quad=$ skor tertinggi likert $\mathrm{x}$ jumlah responden

Skor Rendah $(\mathrm{Y}) \quad=$ skor terendah likert $\mathrm{x}$ jumlah responden

Agar dapat menginterprestasi hasil angket faktor membaca diperlukan rumus index \% yaitu:

$$
\text { Index } \%=\text { total skor/skor ideal } * 100
$$

Adapun cara menentukan interval dan interprestasi persen menggunakan rumus interval, yaitu $1=100 /$ jumlah skor likert $(1=100 / 3=33,3)$. Berikut disajikan kategori interprestasi skor berdasarkan hasil perhitungan interval.

Tabel 1. Interprestasi Skor

\begin{tabular}{cc}
\hline Rentang Skor & Kategori \\
\hline $66,8 \%-100 \%$ & Tinggi \\
$33,4 \%-66,7 \%$ & Cukup \\
$0 \%-33,3 \%$ & Rendah \\
\hline
\end{tabular}

Berikut ini kriteria penilaian menulis teks eksplanasi, yaitu

Tabel 2. Kriteria Penilaian Menulis Teks Eksplanasi

\begin{tabular}{lll}
\hline No. & \multicolumn{1}{c}{ Aspek } & Skor \\
\hline 1 & Pengembangan ide & 20 \\
2 & Struktur penulisan & 15 \\
3 & Penggunaan konjungsi & 15 \\
4 & Penjelasan fenomena & 20 \\
5 & Penggunaan istilah & 10 \\
6 & Interpretasi/simpulan & 20 \\
\hline
\end{tabular}

Kemudian jumlah skor dalam kriteria penilaian menjadi nilai keseluruhan yang didapatkan oleh seorang siswa. Langkah selanjutnya yaitu menghitung rerata nilai siswa dengan rumus:

$$
\overline{\mathrm{X}}=\frac{\sum n}{N} \text { (Nurgiyantoro, 2012) }
$$

Keterangan: $\sum n \quad=$ jumlah skor

$$
\begin{aligned}
& \mathrm{N}=\text { Jumlah Siswa } \\
& \overline{\mathrm{X}}=\text { Nilai Rata-rata }
\end{aligned}
$$

Selanjutnya melakukan penilaian aspek menulis dengan menggunakan rumus:

Jumlah nilai $\mathrm{x}$ jumlah responden 
Penentuan kategori dengan perhitungan presentase hasil kemampuan menulis mengacu pada patokan skala 5 yang diadaptasi dari kategori pilihan milik Nurgiyantoro (2012).

Tabel 3. Kategori Penilaian Nurgiyantoro

\begin{tabular}{ccl}
\hline Skala & Rentang Nilai & \multicolumn{1}{c}{ Kategori } \\
\hline 5 & $81-100$ & Kemampuan menulis sangat tinggi \\
4 & $61-80$ & Kemampuan menulis tinggi \\
3 & $41-60$ & Kemampuan menulis cukup \\
2 & $21-40$ & Kemampuan menulis kurang \\
1 & $0-20$ & Kemampuan menulis sangat kurang \\
\hline
\end{tabular}

Uji instrumen tersebut dilakukan untuk mengetahui bahwa soal yang diberikan kepada siswa tersebut valid atau reliabel. Uji kevalidan instrumen menggunakan rumus koreksi yang dikemukakan oleh Pearson, yaitu korelasi product moment, sebagai berikut.

Keterangan:

$$
\boldsymbol{r} \boldsymbol{x y}=\frac{\boldsymbol{N} \sum X Y-\left(\sum X\right)\left(\sum y\right)}{\sqrt{\left.\left\{N \sum X\right)^{2}\right\}\left\{N \sum Y^{2}-\left(\sum Y\right)^{2}\right\}}}
$$

$$
\begin{array}{ll}
\text { rxy } & =\text { koefisien korelasi antara variabel } \mathrm{x} \text { dan variabel y } \\
\mathrm{X} & =\text { skor dari tes pertama (Instrumen A) } \\
\mathrm{XY} & =\text { skor dari tes kedua (instrumen } \mathrm{B}) \\
\mathrm{X} 2 & =\text { kuadrat skor instrumen A } \\
\mathrm{Y} 2 & =\text { kuadrat instrumen } \mathrm{B} \\
\mathrm{N} & =\text { jumlah instrumen }
\end{array}
$$

Adapun tingkat korelasinya berdasarkan ketentuan bahwa jika $\mathbf{r}_{\text {hitung }}>$

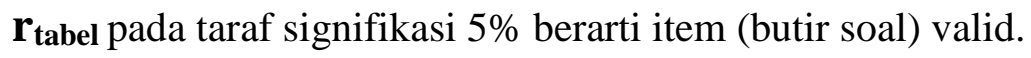

\section{HASIL DAN PEMBAHASAN}

Hasil observasi awal dan tes awal menulis teks eksplanasi yang telah dilakukan kepada siswa bahwa kemampuan siswa di kelas XI MIA-1 SMA Negeri 1 Labuhan Deli masih yaitu 55,88 dalam kategori cukup. Hal ini karena model pembelajaran yang digunakan oleh guru masih konvesional yaitu model pembelajaran struktural.

\section{Pengembangan Model Pembelajaran Berbasis Proyek}

Pengembangan model pembelajaran berbasis proyek mengacu pada hasil obsevasi, yaitu hasil angket analisis kebutuhan dan hasil tes menulis teks eksplanasi. Dari data yang diperoleh tersebut akan dikembangkan menjadi model pembelajaran yang sesuai dengan kebutuhan dan kondisi siswa. 
Dalam proses belajar yang berlangsung siswa seperti biasa melaksanakan kegiatan belajar di dalam kelas tanpa menyadari bahwa kegiatan sedang diobservasi sehingga hasil observasi mendapatkan hasil yang lebih nyata tanpa dibuat-buat. Proses pembelajaran dilanjutkan pada materi yang baru, guru menggunakan pendekatan komunikatif untuk membangkitkan dan membangun situasi yang lebih akrab dan dinamis. Penggunaan pendekatan komunikatif oleh guru membuat interaksi siswa dan guru lebih baik sehingga terjadi tanya jawab antara guru dengan siswa, siswa dengan guru, dan siswa dengan siswa. Untuk mendukung pendekatan komunikatif tersebut guru menggunakan metode ceramah, diskusi, tanya jawab, dan demontrasi. Dengan metode tersebut siswa, lebih aktif dan konsentrasi dalam mengikuti pembelajaran.

Evaluasi yang dipergunakan guru untuk menguji pemahaman siswa usai proses pembelajaran adalah evalauasi bentuk kuis. Evaluasi bentuk kuis efektif untuk menguji pemahaman siswa dengan waktu yang singkat. Kegiatan selanjutnya mengulang materi secara singkat dan bersama siswa membuat simpulan pelajaran. Sebelum akhir pembelajaran, guru memberi tugas kelompok berupa proyek membuat atau menulis teks berdasarkan pengamatan pada siswa sebagai pengayaan materi.

Hasil observasi yang dilakukan di kelas XI MIA-1 SMA Negeri 1 Labuhan Deli maka dipilih pengembangan model pembelajaran berbasis proyek untuk meningkatkan kemampuan menulis teks eksplanasi.

Analisis kebutuhan diujikan pada responden untuk mendapatkan dan mengetahuan kebutuhan yang diperlukan dalam pengembangan model pembelajaran berbasis proyek untuk meningkatkan kemampuan menulis teks eksplanasi. Angket analisis kebutuhan berjumlah 30 butir, namun setelah diuji coba ternyata ada 2 yang tidak valid. Dengan demikian, angket analisis kebutuhan hanya 28 butir.

Untuk mengetahui kemampuan siswa dalam menulis teks eksplanasi maka dilakukan tes awal sebelum dilakukan pengembangan model pembelajaran berbasis proyek. Dari hasil tes keterampilan siswa dalam menulis teks eksplanasi yang diperoleh, diketahui bahwa nilai terendah yang diperoleh siswa adalah 34 dan nilai tertinggi yang diperoleh siswa adalah 72, dengan nilai rerata secara keseluruhan sebesar 55,88. Apabila nilai rerata tersebut dikonsultasikan dengan 


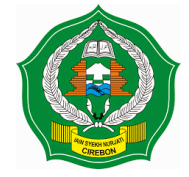

kriteria penilaian, maka perolehan nilai tersebut berada pada kriteria cukup. Dengan demikian, disimpulkan bahwa keterampilan siswa dalam menulis teks eksplanasi oleh siswa kelas XII SMA Negeri 1 Labuhan Deli Tahun Pelajaran 2018-2019 sebelum pengembangan model pembelajaran berada pada kategori cukup. Kelas interval nilai siswa dengan nilai tertinggi, yaitu 72 dan terendah 39 . Distribusi frekuensi dari nilai keterampilan siswa dalam menulis teks eksplanasi sebelum dilakukan pengembangan model pembelajaran sebagai berikut.

Tabel 4. Distribusi Frekuensi Skor Sebelum Pengembangan Model Pembelajaran

\begin{tabular}{cccc}
\hline No. & $\begin{array}{c}\text { Interval } \\
\text { Kelas }\end{array}$ & Frekuensi & Persentase \\
\hline 1 & $39-43$ & 7 & $21 \%$ \\
2 & $44-48$ & 2 & $6 \%$ \\
3 & $49-53$ & 4 & $12 \%$ \\
4 & $54-58$ & 5 & $15 \%$ \\
5 & $59-63$ & 6 & $18 \%$ \\
6 & $64-68$ & 6 & $18 \%$ \\
7 & $69-73$ & 4 & $12 \%$ \\
\hline Jumlah & $\mathbf{3 4}$ & $\mathbf{1 0 0 \%}$ \\
\hline
\end{tabular}

Hasil perhitungan menjelaskan bahwa nilai rerata keterampilan menulis teks eksplanasi yang diperoleh siswa, yaitu 55,88. Oleh karena itu, rerata tingkat keterampilan menulis teks eksplanasi oleh siswa XI MIA-1 SMA Negeri 1 Labuhan Deli Tahun Pelajaran 2018-2019 dapat dikatakan cukup. Hal tersebut terbukti dari 34 siswa diperoleh nilai rerata sebesar 55,88 dan berada kategori cukup. Hasil analisis tes ini tidak selaras dengan hasil angket kebutuhan pengembangan yang berkategori tinggi.

Berdasarkan hasil angket analisis kebutuhan pengembangan model pembelajaran berbasis proyek dapat diketahui bahwa tingkat minat dan kebiasaan menulis siswa termasuk dalam kategori tinggi, karena hasil analisis angket kebutuhan siswa berada pada kategori tinggi. Berdasarkan angket dapat diketahui faktor internal dan faktor eksternal yang sangat erat memengaruhi keterampilan siswa dalam menggunakan kalimat efektif. Pengembangan model pembelajaran yang akan dihasilkan akan menutup kekurangan yang dimiliki siswa dan meningkatkan keterampilan menulis teks eksplanasi yang telah dimiliki sebelumnya. 


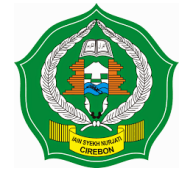

Hasil penelitian ini menunjukkan bahwa terjadi ketidakselarasan antara angket kebutuhan dan hasil tes. Angket kebutuhan pengembangan menunjukkan pada kategori tinggi, sedangkan hasil tes tergolong dalam ketegori cukup. Kedua hasil tersebut akan dipadukan sehingga menghasilkan bahan baru yang mampu meningkatkan keterampilan siswa dalam menulis teks eksplanasi.

Setelah tahap analisis kebutuhan melalui observasi dan angket dilaksanakan, langkah berikutnya, yaitu merancang model pembelajaran berbasis proyek dalam meningkatkan keterampilan menulis teks eksplanasi. Tahap ini menghasilkan produk pembelajaran menulis teks eksplanasi yang sifatnya baru berdasarkan data yang diperoleh selama penelitian. Materi yang digunakan berkaitan dengan teori model pembelajaran berbasis proyek dan menulis teks eksplanasi. Selain itu terdapat Rencana Pelaksanaan Pembelajaran (RPP) yang akan membantu siswa dalam memahami tata cara menulis teks eksplanasi.

\section{Implementasi Desain}

Pelaksanaan implementasi model pembelajaran ini disesuaikan dengan kondisi dan minat siswa sehingga melalui model pembelajaran berbasis proyek yang disajikan siswa mulai terbiasa menulis teks eksplanasi. Langkah-langkah implementasi model pembelajaran berbasis proyek: 1) penentuan pertanyaan mendasar; 2) mendesain perencanaan proyek; 3) menyusun jadwal; dan 4) memonitor peserta didik dan kemajuan proyek. Setelah model pembelajaran berbasis proyek diimplementasikan, langkah berikutnya, yaitu evaluasi dengan memberikan pos-tes.

Dari hasil tes keterampilan siswa dalam menulis teks eksplanasi dapat diketahui bahwa nilai terendah yang diperoleh siswa adalah 50 dan nilai tertinggi 95. Berarti nilai rerata sebesar 78,32 dengan kriteria baik. Dengan demikian, disimpulkan bahwa keterampilan menulis teks eksplanasi oleh siswa kelas XII SMA Negeri 1 Labuhan Deli Tahun Pelajaran 2018-2019 sebelum pengembangan model pembelajaran berada pada kategori baik.

Dari tabel di atas, selanjutnya adalah menentukan kelas interval nilai siswa dengan nilai tertinggi yaitu 95 dan terendah 50. Distribusi frekuensi dari nilai keterampilan siswa dalam menulis teks eksplanasi setelah dilakukan pengembangan model pembelajaran sebagai berikut. 
Tabel 5. Distribusi Frekuensi Skor Setelah Pengembangan Model Pembelajaran

\begin{tabular}{cccc} 
No. & Interval Kelas & Frekuensi & Persentase \\
\hline 1 & $50-54$ & 2 & $6 \%$ \\
2 & $55-59$ & 2 & $6 \%$ \\
3 & $60-64$ & 3 & $9 \%$ \\
4 & $65-69$ & 0 & $0 \%$ \\
5 & $70-74$ & 0 & $0 \%$ \\
6 & $75-79$ & 9 & $26 \%$ \\
7 & $80-84$ & 4 & $12 \%$ \\
8 & $85-89$ & 7 & $21 \%$ \\
9 & $90-94$ & 5 & $15 \%$ \\
10 & $95-99$ & 2 & $6 \%$ \\
\hline & Jumlah & $\mathbf{3 4}$ & $\mathbf{1 0 0 \%}$ \\
\hline
\end{tabular}

Dari hasil pos-tes dapat disimpulkan bahwa keterampilan siswa dalam menulis teks deskripsi oleh siswa kelas XI, MIA-1 SMA Negeri 1 Labuhan Deli Tahun Pelajaran 2018/2019 sebelum pengembangan model pembelajaran berada pada kategori baik.

\section{Kelayakan Model Pembelajaran Berbasis Proyek}

Model pembelajaran berbasis proyek dalam penelitian pengembangan ini kemudian diserahkan kepada dosen ahli untuk dilakukan validasi sehingga dapat diketahui apa saja kelemahan dan kekuatannya. Berdasarkan hasil validasi didapatkan tingkat kelayakan produk yang telah dihasilkan. Validasi dilakukan dengan menggunakan pedoman kriteria skor skala lima sebagai berikut.

\begin{tabular}{|c|c|}
\hline Inerval Skor & Kategori \\
\hline$X>5$ & Sngat Baik \\
\hline $3,1<X \leq 4,2$ & Baik \\
\hline $2,6<X \leq 2,9$ & Cukup \\
\hline $1,8<X \leq 2,5$ & Kurang \\
\hline$<1,8$ & Sangat Kurang \\
\hline
\end{tabular}

Terdapat tiga aspek yang dinilai dalam proses validasi, yaitu aspek kelayakan materi, aspek penyajian, dan aspek bahasa. Hasil penilaian yang telah dilakukan dosen ahli kemudian dijadikan dasar untuk melakukan perbaikan, terutama pada hal-hal yang dapat meningkatkan kualitas model pembelajaran. Berikut hasil dari tiap aspek yang dinilai. 


\section{Aspek Kelayakan Materi}

Berdasarkan penghitungan validasi aspek isi skor rerata validasi adalah 4,22 dengan kategori baik. Hasil validasi aspek kelayakan materi dapat dilihat di bawah ini.

Tabel 7. Kelayakan Materi

\begin{tabular}{|c|c|c|c|c|c|c|c|}
\hline \multirow[b]{2}{*}{ No } & \multirow[b]{2}{*}{ Aspek } & \multirow[b]{2}{*}{ Aspek yang Dinilai } & \multicolumn{5}{|c|}{ Skor } \\
\hline & & & 1 & 2 & 3 & 4 & 5 \\
\hline 1 & $\begin{array}{l}\text { Kesesuaian Materi dengan SK } \\
\text { dan KD }\end{array}$ & $\begin{array}{l}\text { Kelengkapan Materi. } \\
\text { Kesesuaian Materi } \\
\text { Kedalaman Materi }\end{array}$ & & & & $\sqrt{ }$ & $\sqrt{ }$ \\
\hline 2 & Keakuratan Materi & $\begin{array}{l}\text { Kakuratan Konsep dan Defenisi } \\
\text { Keakuratan Fakta } \\
\text { Keakuratan Contoh dan Kasus }\end{array}$ & & & & $\begin{array}{l}\sqrt{ } \\
\sqrt{ }\end{array}$ & $\sqrt{ }$ \\
\hline 3 & Mendorong Keingintahuan & $\begin{array}{l}\text { Keakuratan Notasi, Simbol, dan Ikon. } \\
\text { Mendorong Rasa Ingin Tahu } \\
\text { Menciptakan Kemampuan Bertanya }\end{array}$ & & & & $\begin{array}{l}\sqrt{ } \\
\sqrt{ } \\
\sqrt{ }\end{array}$ & \\
\hline & & $\begin{array}{l}\text { Jumlah } \\
\text { Rata-Rata } \\
\text { Kategori }\end{array}$ & & & $\begin{array}{r}38 \\
1,22 \\
\text { Baik }\end{array}$ & & \\
\hline
\end{tabular}

\section{Aspek Kelayakan Penyajian Materi}

Berdasarkan hasil analisis aspek kelayakan penyajian materi bahwa skor rata-rata validasi adalah 4,28 dengan kategori baik. Hasil validasi aspek kelayakan penyajian materi dapat dilihat di bawah ini.

\section{Tabel 8. Kelayakan Penyajian Materi}

\begin{tabular}{|c|c|c|c|c|c|c|c|}
\hline \multirow{2}{*}{ No } & \multirow{2}{*}{ Aspek } & \multirow{2}{*}{ Aspek yang Dinilai } & \multicolumn{5}{|c|}{ Skor } \\
\hline & & & 1 & 2 & 3 & 4 & 5 \\
\hline \multirow[t]{2}{*}{1} & $\begin{array}{l}\text { Konsistensi dan Keruntunan } \\
\text { Penyajian }\end{array}$ & $\begin{array}{l}\text { Konsistensi sistematikan sajian dalam kegiatan } \\
\text { belajar }\end{array}$ & & & & $\sqrt{1}$ & \\
\hline & & Keruntunan Konsep & & & & $\sqrt{ }$ & \\
\hline \multirow[t]{3}{*}{2} & Penyusunan soa-soal yang & Pemberian Pre-tes & & & & & $\sqrt{ }$ \\
\hline & sesuai dengan kegiatan & Contoh-contoh soal dan penyelesaiannya & & & & $\sqrt{ }$ & \\
\hline & pembelajaran & $\begin{array}{l}\text { Pemberian Pos-tes sebagai umpan balik } \\
\text { penguasaan materi }\end{array}$ & & & & & $\sqrt{ }$ \\
\hline \multirow[t]{5}{*}{3} & Penguatan materi & Refleksi penguasaan materi & & & & $\sqrt{ }$ & \\
\hline & pembelajaran & Pembuatan Rangkuman Materi & & & & $\sqrt{ }$ & \\
\hline & & Jumlah & & & 3 & & \\
\hline & & Rata-Rata & & & 4,2 & & \\
\hline & & Kategori & & & $\mathbf{B a}$ & & \\
\hline
\end{tabular}

\section{Aspek Kelayakan Bahasa}

Berdasarkan analisis data validasi aspek kelayakan bahasa diketahui skor rata-rata validasi adalah 4,16 dengan kategori baik. Hasil validasi aspek kelayakan kegrafisan dapat dilihat dibawah ini. 
Tabel 9. Kelayakan Bahasa

\begin{tabular}{|c|c|c|c|c|c|c|c|c|}
\hline \multirow{2}{*}{ No. } & \multirow{2}{*}{ Aspek } & \multirow{2}{*}{$\begin{array}{l}\text { Aspek yang } \\
\text { Dinilai }\end{array}$} & \multirow{2}{*}{ Hal yang Dinilai } & \multicolumn{5}{|c|}{ Skor } \\
\hline & & & & 1 & 2 & 3 & 4 & 5 \\
\hline \multirow[t]{17}{*}{1} & Bahasa dan & Kesesuaian & Pemahaman terhadap pesan atau informasi. & & & & & $\sqrt{ }$ \\
\hline & Keterbacaan & Bahasa & Kemampuan memotivasi peserta didik. & & & & $\sqrt{ }$ & \\
\hline & & dengan & Kemampuan mendorong berpikir kritis. & & & & $\sqrt{ }$ & \\
\hline & & Peserta & Kesesuaian dengan perkembangan intelektual & & & & $\sqrt{ }$ & \\
\hline & & Didik & peserta didik. & & & & & \\
\hline & & & $\begin{array}{l}\text { Kesesuaian dengan tingkat perkembangan } \\
\text { emosional peserta didik. }\end{array}$ & & & & $\sqrt{ }$ & \\
\hline & & Struktur dan & Ketepatan struktur kalimat. & & & & $\sqrt{ }$ & \\
\hline & & Keefektifan & Keefektifan kalimat. & & & & $\sqrt{ }$ & \\
\hline & & Kalimat & & & & & & \\
\hline & & Penggunaan & Kebakuan istilah. & & & & $\sqrt{ }$ & \\
\hline & & Tata & Konsistensi penggunaan istilah. & & & & $\sqrt{ }$ & \\
\hline & & Bahasa,Istil & Ketepatan ejaan. & & & & & $\sqrt{ }$ \\
\hline & & ah,dan & Konsistensi penggunaan simbol atau ikon. & & & & $\sqrt{ }$ & \\
\hline & & Ejaan & Ketepatan tata bahasa & & & & $\sqrt{ }$ & \\
\hline & & & Jumlah & & & 50 & & \\
\hline & & & Rata-rata & & & 1.16 & & \\
\hline & & & Kategori & & & Bai & & \\
\hline
\end{tabular}

\section{Aspek Kelayakan Grafis}

Berdasarkan hasil analisis aspek kelayakan grafis bahwa skor rata-rata validasi adalah 4,28 dengan kategori baik. Hasil validasi aspek kelayakan penyajian materi dapat dilihat di bawah ini.

Tabel 10. Kelayakan Grafis

\begin{tabular}{|c|c|c|c|c|c|c|c|}
\hline \multirow{2}{*}{ No. } & \multirow{2}{*}{ Indikator } & \multirow{2}{*}{ Aspek Yang Dinilai } & \multicolumn{5}{|c|}{ Skor } \\
\hline & & & 1 & 2 & 3 & 4 & 5 \\
\hline 1 & Ukuran Modul & Kesesuaian ukuran dengan materi isi modul. & & & & $\sqrt{ }$ & \\
\hline 2 & Desain Sampul & Kemenarikan sampul & & & & & $\sqrt{ }$ \\
\hline \multirow[t]{10}{*}{3} & Desain Isi & -Konsistensi Tata Letak & & & & $\sqrt{ }$ & \\
\hline & & -Unsur Tata Letak Harmonis & & & & $\sqrt{ }$ & \\
\hline & & -Unsur Tata Letak Lengkap & & & & $\sqrt{ }$ & \\
\hline & & -Tipografi Isi Modul Sederhana & & & & $\sqrt{ }$ & \\
\hline & & -Tipografi Isi Modul & & & & $\sqrt{ }$ & \\
\hline & & Memudahkan Pemahaman & & & & & \\
\hline & & -Ilustrasi Isi & & & & & $\sqrt{ }$ \\
\hline & & Jumlah & & & 34 & & \\
\hline & & Rata-Rata & & & 4,25 & & \\
\hline & & Kategori & & & Bail & & \\
\hline
\end{tabular}

Berdasarkan hasil validasi dosen ahli rerata aspek kelayakan materi sebesar 4,22 dengan ketegori baik. Kemudian pada aspek kelayakan penyajian materi diperoleh skor rata-rata validasi sebesar 4,28 dengan ketegori baik, aspek kelayakan bahasa diketahui skor rata-rata validasi adalah 4,16 dengan kategori baik,dan aspek kelayakan grafis 4,25 dengan kategori baik. Dengan demikian dapat disimpulkan bahwa model pembelajaran kolaboratif layak digunakan dalam meningkatkan keterampilan menulis teks eksplanasi oleh siswa kelas XII SMA Negeri 1 Labuhan Deli Tahun Pelajaran 2018-2019. 
Berdasarkan hasil observasi, proses belajar mengarahkan siswa kelas XI MIA-1 SMA Negeri 1 Labuhan Deli untuk menulis teks eksplanasi. Keterampilan menulis harus dibiasakan oleh siswa agar pengetahuan awal tentang menulis diperdalam saat berlangsungnya proses belajar dengan guru. Selama proses belajar, guru selalu mengajukan pertanyaan-pertanyaan dan meminta siswa untuk memberikan contoh yang relevan dengan materi yang sedang dibahas.

\section{Keefektifan Pengembangan Model Pembelajaran Berbasis Proyek}

Berdasarkan hasil perhitungan yang telah dilakukan, menunjukkan bahwa nilai rerata keterampilan menulis teks eksplanasi yang diperoleh siswa sebelum dilakukan pengembangan model pembelajaran berbasis proyek, yaitu sebesar 55,88. Dengan demikian, rerata tingkat keterampilan menulis teks eksplanasi oleh siswa kelas XI MIA-1 SMA Negeri 1 Labuhan Deli Tahun Pelajaran 2018-2019 sebelum dilakukan pengembangan model pembelajaran berbasis proyek dapat dikatakan cukup.

Hasil pengembangan model pembelajaran berbasis proyek dan implementasinya menunjukkan bahwa rerata keterampilan menulis teks eksplanasi yang dimiliki siswa yaitu sebesar 78,32.

\section{SIMPULAN}

Proses pengembangan model pembelajaran berbasis proyek dalam meningkatkan keterampilan menulis teks eksplanasi pada siswa XI MIA 1 SMA Negeri 1 Labuhan Deli Tahun Pelajaran 2018-2019, yaitu 1) mengorientasikan siswa, 2) membentuk kelompok, 3) menyusun tugas pembelajaran, 4) memfasilitasi kolaborasi siswa, serta 5) memberi nilai dan mengevaluasi pembelajaran berbasis proyek.

\section{DAFTAR PUSTAKA}

Abidin, Z. (2007). Analisis Eksistensial. Jakarta: PT. Raja Grafindo Persada.

Azkia, H. \& Isnandab, R. (2018). Pengaruh Model Pembelajaran Discovery Learning Terhadap Keterampilan Menulis Teks Eksplanasi Siswa Kelas VII MTSN Durian Tarung Padang. BAHASTRA, 38 (2), 95 - 98. DOI: doi.org/10.26555/bahastra.v38i2.8495. 
Khairullah, Syambasril, \&Wartiningsih, A. (2019). Pembelajaran Menulis Teks Eksplanasi Pada Siswa Kelas XI SMAS Mujahidin Pontianak Tahun Ajaran 2018/2019. Jurnal Pendidikan dan Pembelajaran Khatulistiwa, 8(3), 1 - 11.

Ngalimun. (2012). Strategi dan Model Pembelajaran. Banjarmasin: Aswaja Pressindo.

Nugraha, V. \& Sari, H. N. (2019). Penggunaan Metode Pembelajaran Berbasis Masalah. Semantik, 8(1), $18-28$.

Nurgiyantoro, B. (2012). Penilaian Pembelajaran Bahasa. Yogyakarta: BPFE Yogyakarta.

Saragih, N. Y. (2013). Pengaruh Penerapan Model Pembelajaran Berbasis Proyek Terhadap Kemampuan Menulis Teks Laporan Hasil Observasi oleh Siswa Kelas VII SMP Negeri 38 Medan Tahun Pembelajaran 2013/2014. Unimed.

Sugiyono. (2010). Metode Penelitian Kuantitatif, Kualitatif, dan R\&D. Bandung: CV Alfabeta.

Susilo, J. (2017). Pembelajaran Memproduksi Teks Eksplanasi Kompleks Menggunakan Pembelajaran Berbasis Proyek untuk Siswa SMK. Deiksis: Jurnal Pendidikan Bahasa dan Sastra Indonesia, 4(2), 76 - 92.

Wardiani, R. \& Mulyaningsih, I. (2015). Kemampuan Menulis Deskripsi (Studi Kasus di Pondok Pesantren Nuurusshiddiiq, Cirebon. Indonesian Language Education and Literature, 1(1), 1-16. doi: 10.24235/ileal.v1i1.36.

Wena, M. (2011). Strategi Pembelajaran Inovatif Kontemporer: Suatu Tinjauan Konseptual Operasional. Jakarta: Bumi Aksara. 